\title{
Cytochrome P450 (version 2019.4) in the IUPHAR/BPS Guide to Pharmacology Database
}

Kathryn Burns ${ }^{1}$ and Nuala Ann Helsby ${ }^{1}$

1. University of Auckland, New Zealand

\begin{abstract}
The cytochrome P450 enzyme family (CYP450), E.C. 1.14.---, were originally defined by their strong absorbance at $450 \mathrm{~nm}$ due to the reduced carbon monoxide-complexed haem component of the cytochromes. They are an extensive family of haem-containing monooxygenases with a huge range of both endogenous and exogenous substrates. These include sterols, fat-soluble vitamins, pesticides and carcinogens as well as drugs. The substrates of some orphan CYP are not known. Listed below are the human enzymes; their relationship with rodent CYP450 enzyme activities is obscure in that the species orthologue may not catalyse the metabolism of the same substrates. Although the majority of CYP450 enzyme activities are concentrated in the liver, the extrahepatic enzyme activities also contribute to patho/physiological processes. Genetic variation of CYP450 isoforms is widespread and likely underlies a significant proportion of the individual variation to drug administration.
\end{abstract}

\section{Contents}

This is a citation summary for Cytochrome P450 in the Guide to Pharmacology database (GtoPdb). It exists purely as an adjunct to the database to facilitate the recognition of citations to and from the database by citation analyzers. Readers will almost certainly want to visit the relevant sections of the database which are given here under database links.

GtoPdb is an expert-driven guide to pharmacological targets and the substances that act on them. GtoPdb is a reference work which is most usefully represented as an on-line database. As in any publication this work should be appropriately cited, and the papers it cites should also be recognized. This document provides a citation for the relevant parts of the database, and also provides a reference list for the research cited by those parts.

Please note that the database version for the citations given in GtoPdb are to the most recent preceding version in which the family or its subfamilies and targets were substantially changed. The links below are to the current version. If you need to consult the cited version, rather than the most recent version, please contact the GtoPdb curators.

\section{Database links}

Cytochrome P450

http://www.guidetopharmacology.org/GRAC/FamilyDisplayForward?familyld=242

CYP1 family 
http://www.guidetopharmacology.org/GRAC/FamilyDisplayForward?familyld=261

Enzymes

\section{CYP1A1}

http://www.guidetopharmacology.org/GRAC/ObjectDisplayForward?objectld=1318

\section{CYP1A2}

http://www.guidetopharmacology.org/GRAC/ObjectDisplayForward?objectld=1319

CYP1B1

http://www.guidetopharmacology.org/GRAC/ObjectDisplayForward?objectld=1320

CYP2 family

http://www.guidetopharmacology.org/GRAC/FamilyDisplayForward?familyld=262

Enzymes

CYP2A6

http://www.guidetopharmacology.org/GRAC/ObjectDisplayForward?objectld=1321 CYP2A7

http://www.guidetopharmacology.org/GRAC/ObjectDisplayForward?objectld=1322 CYP2A13

http://www.guidetopharmacology.org/GRAC/ObjectDisplayForward?objectld=1323 CYP2B6

http://www.guidetopharmacology.org/GRAC/ObjectDisplayForward?objectld=1324 CYP2C8

http://www.guidetopharmacology.org/GRAC/ObjectDisplayForward?objectld=1325

CYP2C9

http://www.guidetopharmacology.org/GRAC/ObjectDisplayForward?objectld=1326 CYP2C18

http://www.guidetopharmacology.org/GRAC/ObjectDisplayForward?objectld=1327 CYP2C19

http://www.guidetopharmacology.org/GRAC/ObjectDisplayForward?objectld=1328

CYP2D6

http://www.guidetopharmacology.org/GRAC/ObjectDisplayForward?objectld=1329 CYP2E1

http://www.guidetopharmacology.org/GRAC/ObjectDisplayForward?objectld=1330 CYP2F1

http://www.guidetopharmacology.org/GRAC/ObjectDisplayForward?objectld=1331 CYP2J2

http://www.guidetopharmacology.org/GRAC/ObjectDisplayForward?objectld=1332 CYP2R1

http://www.guidetopharmacology.org/GRAC/ObjectDisplayForward?objectld=1333

CYP2S1

http://www.guidetopharmacology.org/GRAC/ObjectDisplayForward?objectld=1334 CYP2U1

http://www.guidetopharmacology.org/GRAC/ObjectDisplayForward?objectld=1335 CYP2W1

http://www.guidetopharmacology.org/GRAC/ObjectDisplayForward?objectld=1336

CYP3 family

http://www.guidetopharmacology.org/GRAC/FamilyDisplayForward?familyld=263

Enzymes

\section{CYP3A4}

http://www.guidetopharmacology.org/GRAC/ObjectDisplayForward?objectld=1337 CYP3A5

http://www.guidetopharmacology.org/GRAC/ObjectDisplayForward?objectld=1338 


\section{CYP3A7}

http://www.guidetopharmacology.org/GRAC/ObjectDisplayForward?objectld=1339 CYP3A43

http://www.guidetopharmacology.org/GRAC/ObjectDisplayForward?objectld=1340

CYP4 family

http://www.guidetopharmacology.org/GRAC/FamilyDisplayForward?familyld=264

Enzymes

\section{CYP4A11}

http://www.guidetopharmacology.org/GRAC/ObjectDisplayForward?objectld=1341 CYP4A22

http://www.guidetopharmacology.org/GRAC/ObjectDisplayForward?objectld=1342 CYP4B1

http://www.guidetopharmacology.org/GRAC/ObjectDisplayForward?objectld=1343 CYP4F2

http://www.guidetopharmacology.org/GRAC/ObjectDisplayForward?objectld=1344 CYP4F3

http://www.guidetopharmacology.org/GRAC/ObjectDisplayForward?objectld=1345 CYP4F8

http://www.guidetopharmacology.org/GRAC/ObjectDisplayForward?objectld=1346 CYP4F11

http://www.guidetopharmacology.org/GRAC/ObjectDisplayForward?objectld=1347

CYP4F12

http://www.guidetopharmacology.org/GRAC/ObjectDisplayForward?objectld=1348 CYP4F22

http://www.guidetopharmacology.org/GRAC/ObjectDisplayForward?objectld=1349 CYP4V2

http://www.guidetopharmacology.org/GRAC/ObjectDisplayForward?objectld=1350 CYP4X1

http://www.guidetopharmacology.org/GRAC/ObjectDisplayForward?objectld=1351 CYP4Z1

http://www.guidetopharmacology.org/GRAC/ObjectDisplayForward?objectld=1352

CYP5, CYP7 and CYP8 families

http://www.guidetopharmacology.org/GRAC/FamilyDisplayForward?familyld=265

Enzymes

Thromboxane synthase(CYP5A1)

http://www.guidetopharmacology.org/GRAC/ObjectDisplayForward?objectld=1353

Prostacyclin synthase(CYP8A1)

http://www.guidetopharmacology.org/GRAC/ObjectDisplayForward?objectld=1356

CYP7A1

http://www.guidetopharmacology.org/GRAC/ObjectDisplayForward?objectld=1354 CYP7B1

http://www.guidetopharmacology.org/GRAC/ObjectDisplayForward?objectld=1355

CYP8B1

http://www.guidetopharmacology.org/GRAC/ObjectDisplayForward?objectld=1357 CYP11, CYP17, CYP19, CYP20 and CYP21 families

http://www.guidetopharmacology.org/GRAC/FamilyDisplayForward?familyld=266

Enzymes

CYP11A1

http://www.guidetopharmacology.org/GRAC/ObjectDisplayForward?objectld=1358

CYP11B1 
http://www.guidetopharmacology.org/GRAC/ObjectDisplayForward?objectld=1359

Aldosterone synthase(CYP11B2)

http://www.guidetopharmacology.org/GRAC/ObjectDisplayForward?objectld=1360

CYP17A1

http://www.guidetopharmacology.org/GRAC/ObjectDisplayForward?objectld=1361

Aromatase(CYP19A1)

http://www.guidetopharmacology.org/GRAC/ObjectDisplayForward?objectld=1362

CYP20A1

http://www.guidetopharmacology.org/GRAC/ObjectDisplayForward?objectld=1363

CYP21A2

http://www.guidetopharmacology.org/GRAC/ObjectDisplayForward?objectld=1364

CYP24, CYP26 and CYP27 families

http://www.guidetopharmacology.org/GRAC/FamilyDisplayForward?familyld=267

Enzymes

CYP24A1

http://www.guidetopharmacology.org/GRAC/ObjectDisplayForward?objectld=1365

CYP26A1

http://www.guidetopharmacology.org/GRAC/ObjectDisplayForward?objectld=1366

CYP26B1

http://www.guidetopharmacology.org/GRAC/ObjectDisplayForward?objectld=1367

CYP26C1

http://www.guidetopharmacology.org/GRAC/ObjectDisplayForward?objectld=1368

Sterol 27-hydroxylase(CYP27A1)

http://www.guidetopharmacology.org/GRAC/ObjectDisplayForward?objectld=1369

CYP27B1

http://www.guidetopharmacology.org/GRAC/ObjectDisplayForward?objectld=1370

CYP27C1

http://www.guidetopharmacology.org/GRAC/ObjectDisplayForward?objectld=1371

CYP39, CYP46 and CYP51 families

http://www.guidetopharmacology.org/GRAC/FamilyDisplayForward?familyld=268

Enzymes

CYP39A1

http://www.guidetopharmacology.org/GRAC/ObjectDisplayForward?objectld=1372

Cholesterol 24-hydroxylase(CYP46A1)

http://www.guidetopharmacology.org/GRAC/ObjectDisplayForward?objectld=1373

Lanosterol 14- $\alpha$-demethylase(CYP51A1)

http://www.guidetopharmacology.org/GRAC/ObjectDisplayForward?objectld=1374

\section{References}

1. Aboraia AS, Makowski B, Bahja A, Prosser D, Brancale A, Jones G and Simons C. (2010) Synthesis and CYP24A1 inhibitory activity of (E)-2-(2-substituted benzylidene)- and 2-(2-substituted benzyl)-6-methoxytetralones. Eur J Med Chem 45: 4427-34 [PMID:20655626]

2. Agarwal V, Kommaddi RP, Valli K, Ryder D, Hyde TM, Kleinman JE, Strobel HW and Ravindranath V. (2008) Drug metabolism in human brain: high levels of cytochrome P4503A43 in brain and metabolism of anti-anxiety drug alprazolam to its active metabolite. PLOS ONE 3: e2337 [PMID:18545703]

3. Androutsopoulos VP, Papakyriakou A, Vourloumis D and Spandidos DA. (2011) Comparative CYP1A1 and CYP1B1 substrate and inhibitor profile of dietary flavonoids. Bioorg. Med. Chem. 19: 2842-9 [PMID:21482471]

4. Benowitz NL. (1988) Drug therapy. Pharmacologic aspects of cigarette smoking and nicotine addition.N. Engl. J. Med. 319: 1318-30 [PMID:3054551] 
5. Bhagwat SS, Gude C, Boswell C, Contardo N, Cohen DS, Dotson R, Mathis J, Lee W, Furness P and Zoganas H. (1992) Thromboxane receptor antagonism combined with thromboxane synthase inhibition. 4. 8-[[(4-Chlorophenyl)sulfonyl]amino]-4-(3-(3-pyridinyl) propyl)octanoic acid and analogs. J. Med. Chem. 35: 4373-83 [PMID:1447738]

6. Bhatnagar AS, Häusler A, Schieweck K, Lang M and Bowman R. (1990) Highly selective inhibition of estrogen biosynthesis by CGS 20267, a new non-steroidal aromatase inhibitor. J. Steroid Biochem. Mol. Biol. 37: 1021-7 [PMID:2149502]

7. Boezio AA, Berry L, Albrecht BK, Bauer D, Bellon SF, Bode C, Chen A, Choquette D, Dussault I and Fang $M$ et al.. (2009) Discovery and optimization of potent and selective triazolopyridazine series of c-Met inhibitors. Bioorg. Med. Chem. Lett. 19: 6307-12 [PMID:19819693]

8. Browne LJ, Gude C, Rodriguez H, Steele RE and Bhatnager A. (1991) Fadrozole hydrochloride: a potent, selective, nonsteroidal inhibitor of aromatase for the treatment of estrogen-dependent disease. J. Med. Chem. 34: 725-36 [PMID:1825337]

9. Bylund J, Hidestrand M, Ingelman-Sundberg M and Oliw EH. (2000) Identification of CYP4F8 in human seminal vesicles as a prominent 19-hydroxylase of prostaglandin endoperoxides. J. Biol. Chem. 275: 21844-9 [PMID:10791960]

10. Cheng JB, Motola DL, Mangelsdorf DJ and Russell DW. (2003) De-orphanization of cytochrome P450 2R1: a microsomal vitamin D 25-hydroxilase. J. Biol. Chem. 278: 38084-93 [PMID:12867411]

11. Christiansen JS. (1985) Glomerular hyperfiltration in diabetes mellitus.Diabet. Med. 2: 235-9 [PMID:2951074]

12. Covey DF and Hood WF. (1982) A new hypothesis based on suicide substrate inhibitor studies for the mechanism of action of aromatase. Cancer Res. 42: 3327s-3333s [PMID:7083195]

13. Crosignani S, Jorand-Lebrun C, Campbell G, Pretre A, Grippi-Vallotton, T, Quattropani, A, BouscaryDesforges G, Bombrun A, Missotten, M and Humbert $Y$ et al.. (2011) Discovery of a Novel Series of CRTH2 (DP2) Receptor Antagonists Devoid of Carboxylic Acids. ACS Med Chem Lett 2: 938-942

14. Denton TT, Zhang $X$ and Cashman JR. (2005) 5-substituted, 6-substituted, and unsubstituted 3heteroaromatic pyridine analogues of nicotine as selective inhibitors of cytochrome P-450 2A6. J. Med. Chem. 48: 224-39 [PMID:15634016]

15. Dutheil F, Dauchy S, Diry M, Sazdovitch V, Cloarec O, Mellottée L, Bièche I, Ingelman-Sundberg M, Flinois JP and de Waziers I et al.. (2009) Xenobiotic-metabolizing enzymes and transporters in the normal human brain: regional and cellular mapping as a basis for putative roles in cerebral function. Drug Metab. Dispos. 37: 1528-38 [PMID:19359404]

16. Faull AW, Brewster AG, Brown GR, Smithers MJ and Jackson R. (1995) Dual-acting thromboxane receptor antagonist/synthase inhibitors: synthesis and biological properties of [2-substituted-4-(3-pyridyl)1,3-dioxan-5-yl] alkenoic acids. J. Med. Chem. 38: 686-94 [PMID:7861416]

17. Fer M, Corcos L, Dréano Y, Plée-Gautier E, Salaün JP, Berthou F and Amet Y. (2008) Cytochromes P450 from family 4 are the main omega hydroxylating enzymes in humans: CYP4F3B is the prominent player in PUFA metabolism. J. Lipid Res. 49: 2379-89 [PMID:18577768]

18. Fitzsimmons ME and Collins JM. (1997) Selective biotransformation of the human immunodeficiency virus protease inhibitor saquinavir by human small-intestinal cytochrome P4503A4: potential contribution to high first-pass metabolism. Drug Metab. Dispos. 25: 256-66 [PMID:9029057]

19. Flockhart DA.. Drug Interactions: Cytochrome P450 Drug Interaction Table. Indiana University School of Medicine (2007).

20. Fontana E, Dansette PM and Poli SM. (2005) Cytochrome p450 enzymes mechanism based inhibitors: common sub-structures and reactivity. Curr. Drug Metab. 6: 413-54 [PMID:16248836]

21. Foti RS, Rock DA, Han X, Flowers RA, Wienkers LC and Wahlstrom JL. (2012) Ligand-based design of a potent and selective inhibitor of cytochrome P450 2C19. J. Med. Chem. 55: 1205-14 [PMID:22239545]

22. Fukami T, Nakajima M, Sakai H, McLeod HL and Yokoi T. (2006) CYP2A7 polymorphic alleles confound the genotyping of CYP2A6*4A allele. Pharmacogenomics J. 6: 401-12 [PMID:16636685]

23. Furster $C$ and Wikvall K. (1999) Identification of CYP3A4 as the major enzyme responsible for 25- 
hydroxylation of 5beta-cholestane-3alpha,7alpha,12alpha-triol in human liver microsomes. Biochim. Biophys. Acta 1437: 46-52 [PMID:9931427]

24. Gomaa MS, Bridgens CE, Veal GJ, Redfern CP, Brancale A, Armstrong JL and Simons C. (2011) Synthesis and biological evaluation of 3-(1H-imidazol- and triazol-1-yl)-2,2-dimethyl-3-[4-(naphthalen-2ylamino)phenyl]propyl derivatives as small molecule inhibitors of retinoic acid 4-hydroxylase (CYP26). J. Med. Chem. 54: 6803-11 [PMID:21838328]

25. Gryglewski RJ, Bunting S, Moncada S, Flower RJ and Vane JR. (1976) Arterial walls are protected against deposition of platelet thrombi by a substance (prostaglandin $\mathrm{X}$ ) which they make from prostaglandin endoperoxides. Prostaglandins 12: 685-713 [PMID:824685]

26. Gryglewski RJ, Szczeklik A, Korbut R, Swies J, Musiał J, Krzanowski M and Maga P. (1995) The mechanism of anti-thrombotic, thrombolytic and fibrinolytic actions of camonagrel--a new thromboxane synthase inhibitor. Wien. Klin. Wochenschr. 107: 283-9 [PMID:7778318]

27. Ha-Duong NT, Dijols S, Marques-Soares C, Minoletti C, Dansette PM and Mansuy D. (2001) Synthesis of sulfaphenazole derivatives and their use as inhibitors and tools for comparing the active sites of human liver cytochromes P450 of the 2C subfamily. J. Med. Chem. 44: 3622-31 [PMID:11606127]

28. Handratta VD, Vasaitis TS, Njar VC, Gediya LK, Kataria R, Chopra P, Newman Jr D, Farquhar R, Guo Z and Qiu Y et al.. (2005) Novel C-17-heteroaryl steroidal CYP17 inhibitors/antiandrogens: synthesis, in vitro biological activity, pharmacokinetics, and antitumor activity in the LAPC4 human prostate cancer xenograft model. J. Med. Chem. 48: 2972-84 [PMID:15828836]

29. Harmon SD, Fang X, Kaduce TL, Hu S, Raj Gopal V, Falck JR and Spector AA. (2006) Oxygenation of omega-3 fatty acids by human cytochrome P450 4F3B: effect on 20-hydroxyeicosatetraenoic acid production. Prostaglandins Leukot. Essent. Fatty Acids 75: 169-77 [PMID:16820285]

30. Hatae T, Hara S, Yokoyama C, Yabuki T, Inoue H, Ullich V and Tanabe T. (1996) Site-directed mutagenesis of human prostacyclin synthase: Alteration of Cys441 of the Cys-pocket, and Glu347 and Arg350 of the EXXR motif. FEBS Lett. 389: 268-72 [PMID:8766713]

31. Hecht SS and Hoffmann D. (1988) Tobacco-specific nitrosamines, an important group of carcinogens in tobacco and tobacco smoke. Carcinogenesis 9: 875-84 [PMID:3286030]

32. Hibi S, Okamoto Y, Tagami K, Numata H, Kobayashi N, Shinoda M, Kawahara T, Harada K, Miyamoto K and Yamatsu I. (1996) Structure-activity relationships of (E)-3-(1,4-benzoquinonyl)-2-[(3-pyridyl)-alkyl]-2propenoic acid derivatives that inhibit both 5-lipoxygenase and thromboxane A2 synthetase. J. Med. Chem. 39: 3148-57 [PMID:8759636]

33. Ishida H, Noshiro M, Okuda K and Coon MJ. (1992) Purification and characterization of 7 alpha-hydroxy-4cholesten-3-one 12 alpha-hydroxylase. J. Biol. Chem. 267: 21319-23 [PMID:1400444]

34. Jin J, An M, Sapienza A, Aiyar N, Naselsky D, Sarau HM, Foley JJ, Salyers KL, Knight SD and Keenan RM et al.. (2008) Urotensin-II receptor antagonists: synthesis and SAR of $\mathrm{N}$-cyclic azaalkyl benzamides. Bioorg. Med. Chem. Lett. 18: 3950-4 [PMID:18573659]

35. Kahraman M, Sinishtaj S, Dolan PM, Kensler TW, Peleg S, Saha U, Chuang SS, Bernstein G, Korczak B and Posner GH. (2004) Potent, selective and low-calcemic inhibitors of CYP24 hydroxylase: 24sulfoximine analogues of the hormone 1alpha,25-dihydroxyvitamin D(3). J. Med. Chem. 47: 6854-63 [PMID:15615534]

36. Khanapure SP, Garvey DS, Janero DR and Letts LG. (2007) Eicosanoids in inflammation: biosynthesis, pharmacology, and therapeutic frontiers. Curr Top Med Chem 7: 311-40 [PMID:17305573]

37. Kharasch ED, Mitchell D, Coles R and Blanco R. (2008) Rapid clinical induction of hepatic cytochrome P4502B6 activity by ritonavir. Antimicrob. Agents Chemother. 52: 1663-9 [PMID:18285471]

38. Lafite P, Dijols S, Buisson D, Macherey AC, Zeldin DC, Dansette PM and Mansuy D. (2006) Design and synthesis of selective, high-affinity inhibitors of human cytochrome P450 2J2. Bioorg. Med. Chem. Lett. 16: 2777-80 [PMID:16495056]

39. LaSala D, Shibanaka Y and Jeng AY. (2009) Coexpression of CYP11B2 or CYP11B1 with adrenodoxin and adrenodoxin reductase for assessing the potency and selectivity of aldosterone synthase inhibitors. Anal. Biochem. 394: 56-61 [PMID:19622340] 
40. Lehmann TP, Wrzesiński T and Jagodziński PP. (2013) The effect of mitotane on viability, steroidogenesis and gene expression in NCl-H295R adrenocortical cells. Mol Med Rep 7: 893-900 [PMID:23254310]

41. Li-Hawkins J, Lund EG, Bronson AD and Russell DW. (2000) Expression cloning of an oxysterol 7alphahydroxylase selective for 24-hydroxycholesterol. J. Biol. Chem. 275: 16543-9 [PMID:10748047]

42. Libè R, Fratticci A and Bertherat J. (2007) Adrenocortical cancer: pathophysiology and clinical management. Endocr. Relat. Cancer 14: 13-28 [PMID:17395972]

43. Lindmark B, Lundahl A, Kanebratt KP, Andersson TB and Isin EM. (2018) Human hepatocytes and cytochrome $\mathrm{P} 450$-selective inhibitors predict variability in human drug exposure more accurately than human recombinant P450s. Br. J. Pharmacol. 175: 2116-2129 [PMID:29574682]

44. Liu J, Taylor SF, Dupart PS, Arnold CL, Sridhar J, Jiang Q, Wang Y, Skripnikova EV, Zhao M and Foroozesh M. (2013) Pyranoflavones: a group of small-molecule probes for exploring the active site cavities of cytochrome P450 enzymes 1A1, 1A2, and 1B1. J. Med. Chem. 56: 4082-92 [PMID:23600958]

45. Mayhoub AS, Marler L, Kondratyuk TP, Park EJ, Pezzuto JM and Cushman M. (2012) Optimization of the aromatase inhibitory activities of pyridylthiazole analogues of resveratrol. Bioorg. Med. Chem. 20: 2427-34 [PMID:22386564]

46. Miller EJ, Jecs E, Truax VM, Katzman BM, Tahirovic YA, Wilson RJ, Kuo KM, Kim MB, Nguyen HH and Saindane MT et al.. (2018) Discovery of Tetrahydroisoquinoline-Containing CXCR4 Antagonists with Improved in Vitro ADMET Properties. J. Med. Chem. 61: 946-979 [PMID:29350534]

47. Mizukami Y, Sumimoto H, Isobe R and Minakami S. (1993) Omega-hydroxylation of lipoxin B4 by human neutrophil microsomes: identification of omega-hydroxy metabolite of lipoxin B4 and catalysis by leukotriene B4 omega-hydroxylase (cytochrome P-450LTB omega). Biochim. Biophys. Acta 1168: 87-93 [PMID:8389204]

48. Muftuoglu $Y$ and Mustata G. (2010) Pharmacophore modeling strategies for the development of novel nonsteroidal inhibitors of human aromatase (CYP19). Bioorg. Med. Chem. Lett. 20: 3050-64 [PMID:20413308]

49. Nakajima M, Kuroiwa $Y$ and Yokoi T. (2002) Interindividual differences in nicotine metabolism and genetic polymorphisms of human CYP2A6. Drug Metab. Rev. 34: 865-77 [PMID:12487152]

50. Nakano M, Kelly EJ and Rettie AE. (2009) Expression and characterization of CYP4V2 as a fatty acid omega-hydroxylase. Drug Metab. Dispos. 37: 2119-22 [PMID:19661213]

51. Nilsson T, Ivanov IV and Oliw EH. (2010) LC-MS/MS analysis of epoxyalcohols and epoxides of arachidonic acid and their oxygenation by recombinant CYP4F8 and CYP4F22. Arch. Biochem. Biophys. 494: 64-71 [PMID:19919823]

52. No authors listed. (2004) Natalizumab: AN 100226, anti-4alpha integrin monoclonal antibody.Drugs $R D$ 5: 102-7 [PMID:15293871]

53. Noshiro M and Okuda K. (1990) Molecular cloning and sequence analysis of cDNA encoding human cholesterol 7 alpha-hydroxylase. FEBS Lett. 268: 137-40 [PMID:2384150]

54. Orr ST, Ripp SL, Ballard TE, Henderson JL, Scott DO, Obach RS, Sun H and Kalgutkar AS. (2012) Mechanism-based inactivation (MBI) of cytochrome P450 enzymes: structure-activity relationships and discovery strategies to mitigate drug-drug interaction risks. J. Med. Chem. 55: 4896-933 [PMID:22409598]

55. Payne EJ, Ingley E, Dick IM, Wilson SG, Bond CS and Prince RL. (2009) In vitro kinetic properties of the Thr201Met variant of human aromatase gene CYP19A1: functional responses to substrate and product inhibition and enzyme inhibitors. J. Clin. Endocrinol. Metab. 94: 2998-3002 [PMID:19470632]

56. Peng CC, Rushmore T, Crouch GJ and Jones JP. (2008) Modeling and synthesis of novel tight-binding inhibitors of cytochrome P450 2C9. Bioorg. Med. Chem. 16: 4064-74 [PMID:18255300]

57. Pinto-Bazurco Mendieta MA, Negri M, Jagusch C, Müller-Vieira U, Lauterbach T and Hartmann RW. (2008) Synthesis, biological evaluation, and molecular modeling of abiraterone analogues: novel CYP17 inhibitors for the treatment of prostate cancer. J. Med. Chem. 51: 5009-18 [PMID:18672868]

58. Plourde PV, Dyroff M and Dukes M. (1994) Arimidex: a potent and selective fourth-generation aromatase inhibitor. Breast Cancer Res. Treat. 30: 103-11 [PMID:7949201]

59. Potter GA, Barrie SE, Jarman M and Rowlands MG. (1995) Novel steroidal inhibitors of human 
cytochrome P45017 alpha (17 alpha-hydroxylase-C17,20-lyase): potential agents for the treatment of prostatic cancer. J. Med. Chem. 38: 2463-71 [PMID:7608911]

60. Randall MJ, Parry MJ, Hawkeswood E, Cross PE and Dickinson RP. (1981) UK-37, 248, a novel, selective thromboxane synthetase inhibitor with platelet anti-aggregatory and anti-thrombotic activity. Thromb. Res.

23: 145-62 [PMID:6795753]

61. Rose KA, Stapleton G, Dott K, Kieny MP, Best R, Schwarz M, Russell DW, Björkhem I, Seckl J and Lathe R. (1997) Cyp7b, a novel brain cytochrome P450, catalyzes the synthesis of neurosteroids 7alpha-hydroxy dehydroepiandrosterone and 7alpha-hydroxy pregnenolone. Proc. Natl. Acad. Sci. U.S.A. 94: 4925-30 [PMID:9144166]

62. Rotstein DM, Kertesz DJ, Walker KA and Swinney DC. (1992) Stereoisomers of ketoconazole: preparation and biological activity. J. Med. Chem. 35: 2818-25 [PMID:1495014]

63. Shahrokh K, Cheatham 3rd TE and Yost GS. (2012) Conformational dynamics of CYP3A4 demonstrate the important role of Arg212 coupled with the opening of ingress, egress and solvent channels to dehydrogenation of 4-hydroxy-tamoxifen. Biochim. Biophys. Acta 1820: 1605-17 [PMID:22677141]

64. Shak S, Reich NO, Goldstein IM and Ortiz de Montellano PR. (1985) Leukotriene B4 omega-hydroxylase in human polymorphonuclear leukocytes. Suicidal inactivation by acetylenic fatty acids. J. Biol. Chem. 260: 13023-8 [PMID:2997155]

65. Sontag TJ and Parker RS. (2002) Cytochrome P450 omega-hydroxylase pathway of tocopherol catabolism. Novel mechanism of regulation of vitamin E status. J. Biol. Chem. 277: 25290-6 [PMID:11997390]

66. Stark K, Dostalek M and Guengerich FP. (2008) Expression and purification of orphan cytochrome P450 4X1 and oxidation of anandamide. FEBS J. 275: 3706-17 [PMID:18549450]

67. Stoilov I, Akarsu AN and Sarfarazi M. (1997) Identification of three different truncating mutations in cytochrome P4501B1 (CYP1B1) as the principal cause of primary congenital glaucoma (Buphthalmos) in families linked to the GLC3A locus on chromosome 2p21. Hum. Mol. Genet. 6: 641-7 [PMID:9097971]

68. Strobl GR, von Kruedener S, Stöckigt J, Guengerich FP and Wolff T. (1993) Development of a pharmacophore for inhibition of human liver cytochrome P-450 2D6: molecular modeling and inhibition studies. J. Med. Chem. 36: 1136-45 [PMID:8487254]

69. Tani N, Juvonen RO, Raunio H, Fashe M, Leppänen J, Zhao B, Tyndale RF and Rahnasto-Rilla M. (2014) Rational design of novel CYP2A6 inhibitors. Bioorg. Med. Chem. 22: 6655-64 [PMID:25458499]

70. von Moltke LL, Greenblatt DJ, Granda BW, Grassi JM, Schmider J, Harmatz JS and Shader RI. (1999) Nefazodone, meta-chlorophenylpiperazine, and their metabolites in vitro: cytochromes mediating transformation, and P450-3A4 inhibitory actions. Psychopharmacology (Berl.) 145: 113-22 [PMID:10445380]

71. Walker KA, Kertesz DJ, Rotstein DM, Swinney DC, Berry PW, So OY, Webb AS, Watson DM, Mak AY and Burton PM et al.. (1993) Selective inhibition of mammalian lanosterol 14 alpha-demethylase: a possible strategy for cholesterol lowering. J. Med. Chem. 36: 2235-7 [PMID:8340925]

72. Watanuki M, Tilley BE and Hall PF. (1978) Cytochrome P-450 for 11beta- and 18-hydroxylase activities of bovine adrenocortical mitochondria: one enzyme or two? Biochemistry 17: 127-30 [PMID:412519]

73. Williams PA, Cosme J, Vinkovic DM, Ward A, Angove HC, Day PJ, Vonrhein C, Tickle IJ and Jhoti H. (2004) Crystal structures of human cytochrome P450 3A4 bound to metyrapone and progesterone. Science 305: 683-6 [PMID:15256616]

74. Wittman M, Carboni J, Attar R, Balasubramanian B, Balimane P, Brassil P, Beaulieu F, Chang C, Clarke $\mathrm{W}$ and Dell $\mathrm{J}$ et al.. (2005) Discovery of a (1H-benzoimidazol-2-yl)-1H-pyridin-2-one (BMS-536924) inhibitor of insulin-like growth factor I receptor kinase with in vivo antitumor activity. J. Med. Chem. 48: 5639-43 [PMID:16134929]

75. Wu S, Moomaw CR, Tomer KB, Falck JR and Zeldin DC. (1996) Molecular cloning and expression of CYP2J2, a human cytochrome P450 arachidonic acid epoxygenase highly expressed in heart. J. Biol. Chem. 271: 3460-8 [PMID:8631948]

76. Yano JK, Denton TT, Cerny MA, Zhang X, Johnson EF and Cashman JR. (2006) Synthetic inhibitors of 
cytochrome P-450 2A6: inhibitory activity, difference spectra, mechanism of inhibition, and protein cocrystallization. J. Med. Chem. 49: 6987-7001 [PMID:17125252]

77. Yeo KR and Yeo WW. (2001) Inhibitory effects of verapamil and diltiazem on simvastatin metabolism in human liver microsomes. Br J Clin Pharmacol 51: 461-70 [PMID:11422004]

78. Yin L, Hu Q, Emmerich J, Lo MM, Metzger E, Ali A and Hartmann RW. (2014) Novel pyridyl- or isoquinolinyl-substituted indolines and indoles as potent and selective aldosterone synthase inhibitors. $J$. Med. Chem. 57: 5179-89 [PMID:24899257]

79. Zeldin DC, DuBois RN, Falck JR and Capdevila JH. (1995) Molecular cloning, expression and characterization of an endogenous human cytochrome P450 arachidonic acid epoxygenase isoform. Arch. Biochem. Biophys. 322: 76-86 [PMID:7574697]

80. Zimmer C, Hafner M, Zender M, Ammann D, Hartmann RW and Vock CA. (2011) N-(Pyridin-3yl)benzamides as selective inhibitors of human aldosterone synthase (CYP11B2). Bioorg. Med. Chem. Lett. 21: 186-90 [PMID:21129965] 